Vol. 8, $n^{\circ} 1 \mid 2004$

Varia

Markus Eder, Crime and Punishment in the Royal Navy of the Seven Year's War, 1755-1763

Aldershot, Ashgate, 2004, 200 pp., ISBN 0-7546-3507-4

\title{
Clive Emsley
}

\section{(2) OpenEdition}

\section{Journals}

Electronic version

URL: https://journals.openedition.org/chs/529

DOI: $10.4000 /$ chs. 529

ISSN: 1663-4837

Publisher

Librairie Droz

Printed version

Date of publication: 1 August 2004

Number of pages: 118-120

ISBN: 2-600-00955-8

ISSN: $1422-0857$

Electronic reference

Clive Emsley, "Markus Eder, Crime and Punishment in the Royal Navy of the Seven Year's War, 1755-1763", Crime, Histoire \& Sociétés / Crime, History \& Societies [Online], Vol. 8, $n^{\circ} 1$ | 2004, Online since 23 February 2009, connection on 23 March 2022. URL: http://journals.openedition.org/chs/529 ; DOI: https:// doi.org/10.4000/chs.529

This text was automatically generated on 23 March 2022.

(C) Droz 


\title{
Markus Eder, Crime and Punishment in the Royal Navy of the Seven Year's
}

\section{War, 1755-1763}

Aldershot, Ashgate, 2004, 200 pp., ISBN 0-7546-3507-4

\author{
Clive Emsley
}

\section{REFERENCES}

Markus Eder, Crime and Punishment in the Royal Navy of the Seven Year's War, 1755-1763, Aldershot, Ashgate, 2004, 200 pp., ISBN 0-7546-3507-4.

1 Criminologists, and others, recognise that most crime is a young man's game. Historians of eighteenth-century England have often remarked on how judges commented that the numbers of offenders brought before them during wartime was significantly lower than in peacetime, and how the population fretted at the end of wars over the return of the demobilised military, trained in the use of arms and brutalised by conflict. Yet if the demands of war temporarily swallowed many of the most criminogenic section of the population, it is remarkable how little time has been spent by historians in investigating the potential for criminal behaviour within the armed forces. Markus Eder's book is to be welcomed for seeking to confront this issue and for trying to situate the structure and practice of naval law within the relatively well-researched area of the Hanoverian criminal law.

2 Eder maintains that the archival material for studying crime in the Royal Navy during the eighteenth century is probably more complete than the material for studying crime in civilian society. There is information extant on virtually all of the naval courtsmartial during the period, while the log-books of individual ships give details of the summary justice administered by ships' captains. Eder draws interesting comparisons and contrasts with the civilian law. First, and perhaps most significantly, while the law administered in petty sessions, quarter sessions and assizes was spread through a 
multitude of statutes and common law precedents, the law administered by courtsmartial and ships' captains was set out in the Articles of War. A new set of these articles was promulgated in 1749 (included here as Appendix 1). In many respects these new articles were more severe than their predecessors of 1661. As with the civilian courts, however, the implementation and enforcement often depended upon the discretion of the presiding officers rather than adherence to the strict letter of the law. Charges could be downgraded to avoid the death penalty; and at times it appears that ships' captains ordered more strokes of the lash as a punishment than the regulation twelve that was authorised. Courts-martial tended to take much longer over hearing offences than assize courts; but there was always the problem, particularly with the summary offences, that a captain could be adjudicating in a case that he himself had initiated. Some offences were unique to the navy, such as various forms of absence without leave from a ship and the loss of a ship which could lead to an entire ship's company being hauled, technically, before a court martial. Some offences crossed the line between naval and civilian law, as when, most obviously, clashes between press-gangs and their prey caused fatalities. Moreover, it seems that some seamen opted to pursue abusive or violent officers through the civilian, rather than the naval courts when seeking redress; while there were relatively few such cases, the damages awarded to such a plaintiff in the civilian courts could be significant. Recent work on the courts of petty and quarter sessions has suggested that different regions administered the laws in different ways; Eder shows that different naval stations had different patterns of naval offence with which to deal, and sometimes also different attitudes towards certain offences. It might have been interesting to pursue this further and to see to what extent different captains may have taken different attitudes towards their crews and their men's behaviour. But what Eder presents is a thoroughly researched description of naval law and an illuminating assessment of how it functioned in a series of different stations.

What Eder does not give his readers is any sense of the scale of petty criminality that the records suggest among sailors. He counts only ten courts-martial dealing with robbery (and the Articles of War appear to have conflated all larceny with robbery). But did captains also deal summarily with the offence? Perhaps the ships' logs do not help here, but a mere ten offences for a body of men the size of the Royal Navy in wartime over a period of seven years seems questionable. Possibly, indeed probably, on the close confines of the lower deck the crew had their own ways of dealing with petty thieves and others who offended against the accepted norms of ship-board life, but Eder does not address the issue. He does, however, consider the deterrent effect of the naval law, and suggest that it functioned more effectively than the deterrent effect of civilian law. His argument here might be challenged. First, there is the age-old but still unresolved question of the extent to which punishment is a deterrent. Simply because naval courts-martial took longer than assize or quarter sessions trials does not mean, necessarily, that they were perceived as more fair by ships' crews. The crowds at Tyburn showed their opinion of verdicts and of different offenders. Similar behaviour would have been difficult on warships where naval discipline militated against crews voicing their opinions. But silence under the muskets of marines does not mean acquiescence or agreement. Moreover the whole idea of a group of condemned men drawing lots to see which among them would be executed may have raised as much disquiet on the lower decks as the apparent lottery of who was to be executed among those convicted by the civilian courts. It has been suggested, after all, that the uncertainty - the lottery - of who would hang after sentences had been passed by the 
assize courts was one reason for Peel launching a reduction in the number of capital crimes in the early nineteenth century.

4 A final quibble: the book is well researched; there is much of significance here; and it makes an important addition to understanding an under-researched area of crime and punishment in Hanoverian Britain. But the whole might have benefited from some tighter and more intrusive editing. Here and there the prose is a little convoluted and there seem more than the usual number of typographical errors in a monograph of this sort.

\section{AUTHORS}

\section{CLIVE EMSLEY}

The Open University, c.emsley@open.ac.uk 